\title{
Feedback Inhibition of Insulin Gene Expression by Insulin
}

\author{
L. Koranyi, ${ }^{*}$ D. E. James, ${ }^{*}$ E. W. Kraegen, ${ }^{\star}$ and M. A. Permutt* \\ Metabolism Division of the Department of Internal Medicine and ${ }^{\ddagger}$ Department of Cell Biology and Physiology, Washington University \\ School of Medicine, St. Louis, Missouri 63110; and ${ }^{\S}$ Garvan Institute of Medical Research, \\ St. Vincent's Hospital, Sydney, New South Wales 2010, Australia
}

\section{Abstract}

To examine the possible involvement of insulin and glucose in regulation of pancreatic islet gene expression, hyperinsulinemic (insulin infusion $4.1 \mathrm{mU} / \mathrm{kg}$ per $\mathrm{min}$ ) clamps were performed for $12 \mathrm{~h}$ in rats at two different levels of glycemia (either 3 or $8 \mathrm{mM}$ ). A control group received a saline infusion for $12 \mathrm{~h}$. At the end of the 12-h study period, pancreatic RNA was extracted, proinsulin and amylin mRNAs were measured on total RNA, and glucokinase and glucose transporter (GLUT-2) mRNAs were measured on poly(A)+ RNA by dot blot analysis. In insulin-infused hypoglycemic rats, there was a $58 \%$ decrement in proinsulin mRNA $(P<0.01)$ relative to levels in controls, with no change in amylin, glucokinase, or islet GLUT-2 mRNAs. In insulin-infused hyperglycemic rats, there was a comparable decrement $(44 \%, P<0.01)$ in proinsulin mRNA and a smaller decrement in GLUT-2 mRNA (32\%, $P<0.05)$, with no change in amylin or glucokinase mRNAs relative to levels in control animals.

These studies suggest that insulin has a negative feedback inhibitory effect on its own synthesis. The mechanism of inhibition is unknown. It could be a direct effect of insulin on its own transcription, or alternatively an indirect effect mediated by humoral or neural factors. Sustained hyperinsulinemia may lead to suppression of normal islet beta cells and may contribute to the ultimate hypoinsulinemia of noninsulin-dependent diabetes mellitus. (J. Clin. Invest. 1992. 89:432-436.) Key words: feedback inhibition • pancreatic islet beta cell proinsulin - amylin • glucokinase - glucose transporter (GLUT-2) gene expression

\section{Introduction}

Feedback inhibition of insulin secretion by insulin was initially observed in 1941 by Best and Haist (1). These results were verified by isolated islet and pancreas perfusion studies in vitro $(2,3)$ and later confirmed in man. The in vivo experiments in man utilized insulin plus glucose infusions to maintain euglycemia and measured inhibition of C-peptide secretion (4-7). The studies documented that in normal man $(4,5,7)$, in obese subjects (4), and in noninsulin-dependent diabetes mellitus subjects (6), both basal and stimulated insulin secretion is inhibited by insulin itself.

Address correspondence to M. Alan Permutt, M.D., Metabolism Division, Washington University School of Medicine, 660 South Euclid, Box 8127, St. Louis, MO 63110.

Received for publication 24 July 1991 and in revised form 18 September 1991.

J. Clin. Invest.

(c) The American Society for Clinical Investigation, Inc.

$0021-9738 / 92 / 02 / 0432 / 05 \quad \$ 2.00$

Volume 89, February 1992, 432-436
The effects of insulin on insulin production by pancreatic islet beta cells have been assessed in rats after chronic administration of insulin and in rats bearing insulinomas (8-10). Both conditions result in marked islet atrophy and suppression of insulin gene expression. The effects of insulin are difficult to interpret in these studies, since the animals were both hyperinsulinemic and hypoglycemic. Because fasted rats are also hypoglycemic but hypoinsulinemic, another condition associated with reduced insulin gene expression, this finding suggested that the major determinant of insulin gene expression is ambient plasma glucose concentrations (11). The question of whether insulin per se regulates its own synthesis has not been rigorously addressed because in none of these studies were plasma insulin levels fixed, and plasma glucose varied.

In the present studies this question was examined by prolonged infusions of insulin while maintaining blood glucose constant at either low or high levels. The results demonstrated that elevated plasma insulin, independent of the ambient glucose concentration, caused a marked reduction in proinsulin mRNA. Other islet beta cell-specific mRNAs, such as the islet glucose transporter (GLUT-2), ${ }^{1}$ glucokinase, and amylin, did not follow this pattern.

\section{Methods}

Experimental animals. Adult male Wistar rats (300-380 g) with free access to water and, when not fasting, to rat chow (65\% energy intake as carbohydrate) were used in these studies. The same rats were also used in a study of GLUT-2 mRNA levels in cardiac and skeletal muscle (Kraegen, E. W., J. A. Sowden, M. B. Halstead, P. W. Clark, C. Campbell, K. J. Rodnick, D. J. Chisholm, and D. E. James, manuscript submitted for publication). Rats were housed in a temperature-controlled room $\left(22 \pm 1^{\circ} \mathrm{C}\right)$ with a 12:12-h light/dark cycle (lights on 0600 ). Rats for metabolic studies were housed in individual cages after cannula implantation.

Influence of hyperinsulinemia on islet gene expression. Rats for hyperinsulinemic clamp studies were fitted with cannulas introduced into the carotid artery and jugular vein as previously described (12). Studies were conducted 3-5 d after catheter implantation, on animals in the unrestrained, sedentary, conscious state after food withdrawal.

To examine the possible involvement of insulin and glucose in regulating islet gene expression, hyperinsulinemic (insulin infusion 4.1 $\mathrm{mU} / \mathrm{kg}$ per $\mathrm{min}$ ) clamps were performed for $12 \mathrm{~h}$. Food was removed from animals at the start of the 12-h study period (0700). Two insulininfused groups were studied, clamped at either a low $(3 \mathrm{mM})$ or high $(8$ $\mathrm{mM}$ ) plasma glucose level by an appropriate variable rate glucose infusion. In addition, a control group (saline infusion only) was studied. Blood samples $(50 \mu \mathrm{l})$ for measuring glucose and adjusting the glucose infusion rate were taken at 20-30-min intervals for $2 \mathrm{~h}$. As glucose requirement varied only slightly after this time, subsequent samples at 60 -min intervals until completion were found to be adequate. Larger

1. Abbreviations used in this paper: GLUT-2, glucose transporter; NEFA, nonesterified fatty acids; PEPCK, phosphoenolpyruvate carboxykinase. 
samples $(400 \mu \mathrm{l})$ were taken at 0,6 , and $12 \mathrm{~h}$ for insulin and nonesterified fatty acids (NEFA) assays. Cells were resuspended and returned after the 0 - and 6-h samples. After $12 \mathrm{~h}$, tissues were removed and rapidly frozen for determination of islet mRNA levels.

Analytic methods: in vivo metabolic studies. Blood and plasma glucose concentrations were determined using a glucose analyzer (model 23AM, Yellow Springs Instrument Co., Yellow Springs, OH). Plasma samples for determination of insulin and NEFA were kept at $-20^{\circ} \mathrm{C}$ until assayed. Insulin was assayed by a double-antibody RIA. Enzymatic colorimetric kits were used to determine plasma concentrations of free fatty acids (NEFAC Code No. 279-75409, Wako Chemical Co., Osaka, Japan).

RNA extraction and DNA determination. Total tissue RNA was extracted with a modified guanidine thiocyanate water-saturated phenol extraction method (13). Pancreata were homogenized in $4 \mathrm{M}$ guanidine thiocyanate containing $1 \%$ of octylphenol-ethylene oxide detergent (Nonidet P-40; Sigma Chemical Co., St. Louis, MO), and, after centrifugation $\left(3,500 \mathrm{~g}\right.$ for $5 \mathrm{~min}$ at $\left.10^{\circ} \mathrm{C}\right), 1 / 20 \mathrm{vol}$ of $2 \mathrm{M} \mathrm{KOAc}$ (pH 5.0), 1/12.5 vol of $1 \mathrm{M} \mathrm{HOAc}$, and $1.5 \mathrm{vol}$ of absolute ethanol were added to the supernatant. After precipitation $\left(4 \mathrm{~h}\right.$ at $\left.-20^{\circ} \mathrm{C}\right)$ and centrifugation $\left(15,000 \mathrm{~g}\right.$ for $10 \mathrm{~min}$ at $\left.+4^{\circ} \mathrm{C}\right)$, the pellet was homogenized in 6 $\mathrm{M}$ guanidine $\mathrm{HCl}$ (containing $0.1 \mathrm{M} \mathrm{KOAc}, \mathrm{pH} 5.), 0.025 \mathrm{M}$ EDTA, $0.1 \mathrm{M} 2-\beta$-mercaptoethanol) and precipitated with $0.5 \mathrm{vol}$ of ethanol $\left(-20^{\circ} \mathrm{C}\right.$, overnight). The samples were centrifuged at the same speed and the pellets were dissolved in $6 \mathrm{M}$ guanidine $\mathrm{HCl}$, and multiple water-saturated phenol/phenol-chloroform-isoamylalcohol/chloroform extractions and ethanol precipitation were performed. After determining the absorbance at 260 and $280 \mathrm{~nm}$, aliquots of RNA were run on minigels to verify the integrity of RNA preparations. The $A_{260 / 280}$ ratios and the $28 \mathrm{~S} / 18 \mathrm{~S}$ RNA ratios were $>2$ for all samples.

DNA concentrations of islet homogenates were measured with a DNA fluorometer (model TKO 100, Hoefer Scientific Instruments, San Francisco, CA) with Hoechst 33258 dye (Polysciences, Inc., Warrington, PA) and calf thymus DNA (Sigma Chemical Co.) as standard.

Hybridization probes. The probes used for mRNA analysis were $(a)$ rat proinsulin I cDNA fragment, 304 bp of coding information (14); (b) a 2.2-kb rat GLUT-2 cDNA isolated from a rat liver cDNA library with a human GLUT-2 clone (15), shown by sequence analysis to be identical to that of the published rat GLUT-2 clone (16); (c) a 441-bp rat islet amylin cDNA fragment (kindly provided by Donald F. Steiner, University of Chicago, Chicago, IL) in PGEM-4Z vector (Promega Corp., Madison, WI); and $(d)$ rat islet glucokinase cDNA (17), kindly provided by Mark Magnuson (Vanderbilt University, Nashville, TN). The cDNA fragments were subcloned in pGEM (Promega Corp.) or Blue- script $\mathrm{SK}^{+}$(Stratagene Inc., La Jolla, CA) plasmids. Uniformly labeled $\left[{ }^{32} \mathrm{P}\right] \mathrm{CRNA}$ probes were transcribed according to a protocol provided by the suppliers and as previously described (18).

Quantitation of islet $m R N A$. Poly(A)+ RNA was isolated from total pancreatic RNA and Northern blot analysis performed according to standard methods (19). Quantitation of all mRNAs concentrations, including proinsulin, GLUT-2, amylin, and glucokinase, was by dot blot hybridization, essentially as described (20). 10-, 5-, and 2.5- $\mu \mathrm{g}$ aliquots of total pancreatic RNA for determination of proinsulin or amylin mRNA, or poly(A)+ RNA for determination of GLUT-2 and glucokinase mRNA, were dissolved in $15 \%$ formaldehyde in $10 \times$ standard saline citrate (SSC), and blotted onto Nytran membranes (Schleicher \& Schuell, Inc., Keene, NH). Membranes were incubated with appropriate probes $\left(5 \times 10^{6} \mathrm{cpm} / \mathrm{ml}\right)$ for $18 \mathrm{~h}$ at $60^{\circ} \mathrm{C}$ in $50 \%$ formamide, $5 \times$ SSPE, and then washed at $60^{\circ} \mathrm{C}$ in $0.1 \%$ SDS. Blots were exposed to Kodak XAR5 film at $-70^{\circ} \mathrm{C}$ using intensifying screens (Cronex Lightning Plus; E. I. Dupont de Nemours Co., Wilmington, DE). The amount of mRNA in each sample, determined in duplicate, was measured by densitometric analysis comparing the intensity of the dots. The coefficients of variation for quantitative dot blot analysis of proinsulin mRNA (see Table I) were such that differences $>35 \%$ would be detected at the $p=0.05$ level.

Membranes were stripped after hybridization and rehybridized with uniformly labeled $\left[{ }^{32} \mathrm{P}\right] \mathrm{actin}$ cRNA $(1,200$-bp chicken beta-actin cDNA subcloned in pGEM-1) as an mRNA control. It was determined, however, that actin mRNA under the conditions studied was not a stable mRNA, but declined with insulin infusions (see Table I). Islet mRNA was, therefore, normalized to DNA concentration of each sample.

Statistical analysis. All experimental data are expressed as mean \pm SEM. Statistical analyses were performed using paired or unpaired two-tailed Student's $t$ tests or a two-way ANOVA as appropriate. $P<0.05$ was considered significant. Correlations were performed by univariate linear regression using the CLINFO Data Analysis System of Washington University General Clinical Research Center (G.C.R.C. RR-00036), supported by the Division of Research of the NIH.

\section{Results}

Effects of insulin infusions on islet gene expression. The effects of 12-h hyperinsulinemic clamps at two different glucose levels on circulating plasma glucose, serum insulin, and NEFA levels are shown in Table I. Plasma glucose was maintained at $3 \mathrm{mM}$ in the low glucose-infused animals and $8 \mathrm{mM}$ in the high glucose-infused animals, compared with $6 \mathrm{mM}$ in control ani-

Table I. Effects of 12-h Hyperinsulinemic Clamps at Two Plasma Glucose Levels on Circulating Factors, Pancreatic RNA and Actin $m R N A$, and Islet mRNAs

\begin{tabular}{|c|c|c|c|}
\hline \multirow[b]{2}{*}{ Group } & \multirow{2}{*}{$\begin{array}{c}\text { Control } \\
\text { saline infusion }\end{array}$} & \multicolumn{2}{|c|}{ Insulin infusion } \\
\hline & & Low glucose & High glucose \\
\hline Plasma glucose $(m M)$ & $6.1 \pm 0.2$ & $3.1 \pm 0.3^{\ddagger}$ & $8.3 \pm 0.5^{\ddagger}$ \\
\hline Serum insulin ( $m U /$ liter $)$ & $6.3 \pm 1.6$ & $120 \pm 3^{\ddagger}$ & $149 \pm 28^{\ddagger}$ \\
\hline Serum NEFA ( $\mathrm{mmol} /$ liter) & $0.9 \pm 0.1$ & $0.4 \pm 0.1^{*}$ & $0.5 \pm 0.1^{*}$ \\
\hline Glucose infusion rate $(\mathrm{mg} / \mathrm{kg}$ per $\mathrm{min}$ ) & & $8.3 \pm 1.4$ & $24.5 \pm 1.6$ \\
\hline RNA yield $(\mu g / \mu g D N A)$ & $2.07 \pm 0.58$ & $1.76 \pm 0.31$ & $1.46 \pm 0.34$ \\
\hline Actin mRNA (OD U/ $\mu g$ DNA) & $5.270 \pm 1.11$ & $2.700 \pm 0.28^{*}$ & $1.162 \pm 0.18^{\ddagger}$ \\
\hline Proinsulin mRNA (OD U/ $\mu g D N A$ ) & $1.155 \pm 0.23$ & $0.484 \pm 0.08^{\ddagger}$ & $0.644 \pm 0.229^{\ddagger}$ \\
\hline Amylin mRNA (OD U/ $\mu g$ DNA) & $0.576 \pm 0.202$ & $0.347 \pm 0.101$ & $0.407 \pm 0.08$ \\
\hline Glucokinase mRNA (OD U/ $\mu g$ DNA) & $1.280 \pm 0.187$ & $1.024 \pm 0.23$ & $0.974 \pm 0.19$ \\
\hline GLUT-2 mRNA (OD U/ $\mu g$ DNA) & $1.990 \pm 0.44$ & $1.710 \pm 0.25$ & $1.357 \pm 0.31^{*}$ \\
\hline
\end{tabular}

Values are expressed as mean $\pm \mathrm{SEM}$ of four to six animals for each group. These animals were also analyzed for another set of experiments as described in Methods. ${ }^{*} P<0.05,{ }^{\ddagger} P<0.01$ compared with control group. NEFA; nonesterified fatty acids; OD, arbitrary densitometric units. 
mals. Insulin infusions raised serum insulin levels to 120-149 $\mathrm{mU} / \mathrm{l}$ and significantly inhibited serum NEFA levels relative to controls. At the end of $12 \mathrm{~h}$, pancreatic RNA was prepared.

Islet beta cell mRNA levels were quantitated by dot blot hybridization analysis with ${ }^{32} \mathrm{P}$-labeled cRNA probes. Initial hybridization conditions were evaluated by Northern blot analysis. A representative Northern blot of pancreatic RNA from control animals and from animals maintained at low or high glucose during insulin infusions, hybridized with ${ }^{32} \mathrm{P}$-labeled proinsulin cRNA, is shown in Fig. 1. Proinsulin mRNA concentrations appeared reduced in both groups of hyperinsulinemic animals (lanes 1 and 2) relative to that in saline-infused control animals (lane 3). This was further quantitated by dot blot analysis.

The results of 12-h hyperinsulinemic clamps at two plasma glucose levels on pancreatic RNA yields and islet mRNA levels quantitated by dot blot analysis are shown in Table I. Although RNA yields were not significantly altered by insulin infusions, there was a trend toward a decrease. Pancreatic actin mRNA was significantly reduced in both experimental conditions, so islet mRNA concentrations were expressed per microgram pancreatic DNA. Insulin infusions with hypoglycemia $(n=5)$ resulted in a $58 \%$ decline in proinsulin mRNA $(P<0.01)$ compared with levels in saline-infused controls $(n=5)$, similar to results previously described (9). In contrast, there were no significant changes noted in amylin, glucokinase, or GLUT-2 mRNAs in insulin-infused hypoglycemic rats.

When animals were made hyperinsulinemic and clamped at high glucose levels, a surprising $44 \%$ reduction in proinsulin mRNA $(P<0.01)$ was observed as well. This condition also resulted in a smaller decline in GLUT-2 mRNA $(32 \%, P$ $<0.05$ ), with no change in amylin mRNA or glucokinase mRNA versus levels in saline-infused control animals.

\section{Discussion}

In this study, evidence is presented that insulin per se may regulate its own synthesis. Previous studies have implicated

\section{Proinsulin mRNA}

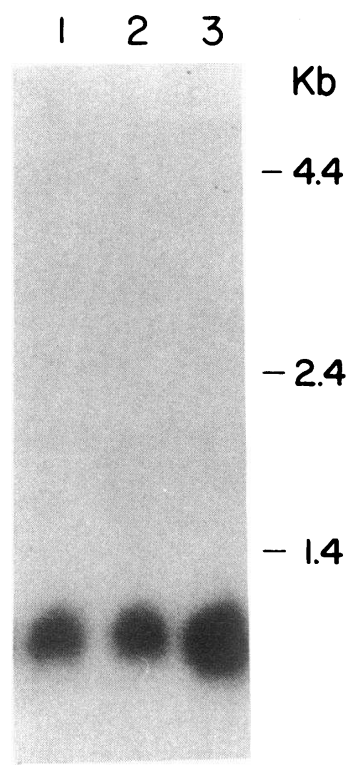

glucose as the major regulatory component (8-11, 21-26). The results of the current study tend to undermine this, since suppression at either low or high glucose levels was observed, whereas the serum insulin was held constant at a level $\sim 20-25$ times the basal concentration. In previous studies in animals bearing insulinomas and in chronic insulin-infused animals, marked suppression of proinsulin mRNA was noted in pancreatic islet beta cells by in situ quantitative hybridization analysis (9). In those studies, the animals were both hyperinsulinemic and hypoglycemic. Only in the current study were animals subjected to a sustained period of hyperinsulinemia while plasma glucose levels were clamped at low or high levels. Under these conditions it appears that insulin itself is responsible for the suppression.

That glucose per se can regulate insulin gene expression appears to have been well established by experiments conducted both in vivo and in vitro. Fasting is associated with low glucose levels and low proinsulin mRNA levels (11). Glucose infusion into rats resulted in hyperglycemia and increased proinsulin mRNA (25). Isolated islets and islet beta cells in culture respond to changes in glucose concentrations with alterations of insulin gene expression $(22-24,26)$. The results of the current studies, however, now suggest that the insulin gene is subject to dual control by both plasma glucose and serum insulin levels. In the presence of hyperinsulinemia and high glucose levels, insulin appeared to have a dominant negative effect on insulin gene expression.

The effects of insulin on insulin gene expression were somewhat specific in that glucokinase and amylin, two other beta cell-specific gene products (27-29), were not changed under these conditions. The GLUT-2 gene was suppressed only at high glucose levels. Thus, the effects of insulin on insulin gene expression were larger and more consistent than these changes in expression of the other islet genes. The effects of insulin infusions in vivo on pancreatic actin mRNA have not been previously reported, but we have noted that actin mRNA is not a stable pancreatic or islet mRNA under several experimental conditions (Koranyi, L., and M. A. Permutt, unpublished observations).

The rather large $(>50 \%)$ reduction in proinsulin mRNA after only $12 \mathrm{~h}$ of insulin infusion was surprising in light of the previously estimated half-life of $>24 \mathrm{~h}$ in rat islets and in cultured insulinoma cells $(23,24)$. If this estimate is representative of the in vivo half-life, then one might conclude that hyperinsulinemia alters mRNA stability. An equally likely interpretation, however, is that half-life estimates of proinsulin mRNA in cultured islets and insulinoma cells are not accurate reflections of the in vivo situation. The estimates of proinsulin mRNA half-life in primary cultures were made after $24 \mathrm{~h}$ of preincubation in vitro, followed by subsequent incubations for up to 60 h. Although these experiments are interesting in their own right, especially with regard to the effects of glucose concentrations on mRNA stability, their relationship to proinsulin mRNA turnover in vivo is unknown. In this regard, the current experiments represent the first approximation of proinsulin mRNA half-life in vivo. Future experiments measuring additional time points and other experimental conditions would be useful in estimating the half-life of proinsulin mRNA and other islet mRNAs as well.

The mechanism of insulin inhibition of its own gene expression is unknown. The inhibitory effect of chronic hyperinsulinemia on proinsulin mRNA expression may be on tran- 
scription of the gene or mRNA stability. The feedback inhibitory effect of insulin may be direct or indirect and mediated by humoral or neural factors, as catecholamines have been shown to be enhanced by hyperinsulinemia (30). If the feedback inhibitory effect is direct, it may alter transcription through interaction with an insulin-regulatory element in the insulin gene. Insulin has been shown to stimulate transcription of a number of genes (31) as well as inhibit transcription of phosphoenolpyruvate carboxykinase (PEPCK), adipsin, and growth hormone genes (32-34). PEPCK is an important rate-limiting enzyme for gluconeogenesis by liver, and the gene appears to be under dual control (33-35). It is positively regulated by cAMP and glucocorticoids, whereas insulin has a dominant inhibitory effect. Recently, hepatoma cells were stably transfected with the promoter region ( -433 to -396$)$ of the PEPCK gene coupled to a reporter gene, and the construct was maximally inhibited in the presence of insulin (32). A 15-bp insulin-response sequence was identified that was active in either orientation. A search of the promoter regions of rat insulins I and II genes revealed a region of $10 \mathrm{bp}$ at -734 of the rat insulin I gene, which was identical to the insulin response sequence of the PEPCK gene (Fig. 2). Extending the search to sequences immediately adjacent to the PEPCK insulin response sequence, a region of $12 \mathrm{bp}$ identity is seen in the rat insulin I promoter. The core sequence TTTTA is also observed in the promoter region of the rat insulin II gene.

This represents the first study of the effects of hyperinsulinemia at both low and high plasma glucose levels on expression of islet amylin, glucokinase, and GLUT-2 genes. The effects of insulin injection and chronic insulin infusions in rats on islet GLUT-2 expression have been reported (10). $3 \mathrm{~h}$ after an insulin injection, islet GLUT-2 mRNA concentration was not changed; but insulin infusion for $4 \mathrm{~d}$ resulted in an $85 \%$ decrease. In the current experiments, after $12 \mathrm{~h}$ of insulin infusion, there was no reduction in GLUT-2 mRNA in hypoglycemic rats relative to controls, but there was a reduction in hyperglycemic animals (Table I). In chronic exercised rats, GLUT-2 mRNA levels were also unchanged (20). For all of the above conditions, as in the current experiments, there was no correlation between proinsulin mRNA and GLUT- 2 mRNA ( $r$ $=0.43, P=0.13$ ). Thus, although the islet GLUT-2 gene may be regulated under some conditions, these data together indicate that it is not coordinately regulated with the insulin gene.

The activity of pancreatic islet glucokinase may be ratelimiting for beta-cell glucose metabolism (27). Few studies have been reported of glucokinase gene expression after in vivo manipulations. No change in islet glucokinase mRNA concentration was observed in fasted rats (28). Chronic training of rats resulted in suppression of both basal and glucose-induced insulin secretion, associated with coordinate reduction of proinsulin and glucokinase mRNAs (20). In the current study, although there was no change in glucokinase mRNA levels, there

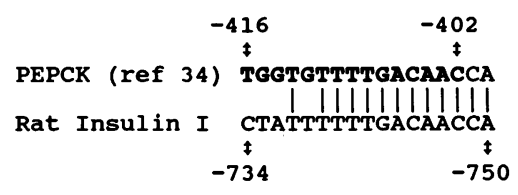

Figure 2. The 15-bp insulin regulatory sequence in the PEPCK promoter (32) is compared with the reverse complement of a region of sequence identity in the promoter of the rat insulin I gene. was a significant correlation between glucokinase mRNA and proinsulin mRNA concentrations ( $r=0.79, P=0.0004)$, suggesting perhaps that expression of these genes is coordinately regulated, as was noted in chronically trained rats (20).

Very little is known about regulation of amylin biosynthesis in man or experimental animals (29). Amylin gene expression in islets is relatively high, being on the order of $10 \%$ that of insulin in the rat (36). Fasting and streptozotocin diabetes were associated with decreased amylin mRNA concentrations (37), whereas administration of pharmacologic glucocorticoids resulted in enhanced insulin and amylin mRNA levels (38). In neonatal rats, both obesity and high carbohydrate feeding were found to have marked stimulatory effects on amylin gene expression (39). In those experiments there was a significant correlation between amylin and insulin gene expression for all animals during development, regardless of diet. In the current studies, although there was a trend toward suppression of amylin gene expression with hyperinsulinemia and hypoglycemia, these changes were not significant. However, the coefficient of variation for amylin mRNA (see Table I) was too large to detect differences this small at the $P=0.05$ level.

The feedback inhibitory effect of insulin on its own expression may be an important physiological control mechanism. In the immediate postprandial period, hyperglycemia stimulates acute insulin release to restore euglycemia. The high concentrations of insulin to which islet beta cells are subjected may have little effect on insulin gene expression, as the insulin levels rapidly fall (minutes to hours) with restoration of plasma glucose concentration. Sustained hyperinsulinemia, however (hours to days), such as occurs during prolonged insulin infusion or in patients with insulin resistance and hyperinsulinemia, may result in suppression of normal islets. This observation raises the intriguing possibility that the hyperinsulinemia that accompanies obesity and the early phases of noninsulindependent diabetes mellitus may contribute to the ultimate development of insulin lack that is characteristic of this disorder.

\section{Acknowledgments}

The laboratory assistance of Cris Welling and Rachel Janssen, the expert assistance of Peter Clark with the physiological studies, and the manuscript preparation by Jeannie Wokurka are gratefully acknowledged. The authors also wish to thank Dr. Daryl Granner (Vanderbilt University, Nashville, TN) for providing data before publication.

This research was supported by NIH grant DK-16746 and a Juvenile Diabetes Foundation Fellowship (L. Koranyi). D. E. James is the recipient of a Career Development Award from the Juvenile Diabetes Foundation. E. W. Kraegen is supported by the National Health and Medical Research Council of Australia. Computing facilities and assistance with data analysis were provided by the Washington University General Clinical Research Center Computing Facilities, which is supported by grant 5M01 RR-00036 from the U. S. Public Health Service.

\section{References}

1. Best, C. H., and R. E. Haist. 1941. The effect of insulin administration on the insulin content of the pancreas. J. Physiol. (Lond.). 100:142-146.

2. Iversen, J., C. Med, D. W. Miles, and M. C. Arhus. 1971. Evidence for a feedback inhibition of insulin secretion in the isolated perfused canine pancreas. Diabetes. 20:1

3. Draznin, B., M. Goodman, J. W. Leitner, and K. E. Sussman. 1986. Feedback inhibition of insulin secretion in isolated pancreatic islets. Endocrinology. 118:1054-1058. 
4. Elahi, D., M. Nagulesparan, R. J. Hershcopf, D. C. Muller, J. D. Tobin, P. M. Blix, A. H. Rubenstein, R. H. Unger, and R. Andres. 1982. Feedback inhibition of insulin secretion by insulin: relation to the hyperinsulinemia of obesity. N. Engl. J. Med. 306:1196-1202.

5. Brodows, R. G. 1985. Starvation enhances the ability of insulin to inhibit its own secretion. Metabolism (Clin. Exp.). 34:53-75.

6. Garvey, W. T., R. R. Revers, O. G. Kolterman, A. H. Rubenstein, and J. M. Olefsky. 1985. Modulation of insulin secretion by insulin and glucose in type II diabetes mellitus. J. Clin. Endocrinol. Metab. 60:559-568.

7. Argoud, G. M., D. S. Schade, and R. P. Eaton. 1987. Insulin suppresses its own secretion in vivo. Diabetes. 36:959-962.

8. Appel, M. C. 1984. Effects of glucose on insulin gene expression. Diabetologia. 27:252a. (Abstr.)

9. Chen, L., T. Alam, J. H. Johnson, S. Hughes, C. B. Newgard, and R. H. Unger. 1990. Regulation of $\beta$-cell glucose transporter gene expression. Proc. Natl. Acad. Sci. USA. 87:4088-4092.

10. Chen, L., I. Komiya, L. Inman, J. O'Neil, M. Appel, T. Alam, and R. H. Unger. 1989. Effects of hypoglycemia and prolonged fasting on insulin and glucagon gene expression: studies with in situ hybridization. J. Clin. Invest. 84:711714.

11. Giddings, S. J., J. Chirgwin, and M. A. Permutt. 1981. The effects of fasting and feeding on preproinsulin messenger RNA in rats. J. Clin. Invest. 67:952-960.

12. Kraegen, E., D. James, S. Bennett, and D. Chisholm. 1983. In vivo insulin sensitivity in the rat determined by euglycemic clamp. Am. J. Physiol. 245:E1E7.

13. Chromczynski, P., and N. Sacchi. 1987. Single step method of RNA isolation by acid guanidium thiocyanate-phenol-chloroform extraction. Anal. Biochem. 162:156-159.

14. Giddings, S. J., and L. R. Carnaghi. 1988. The two non-allelic rat insulin mRNAs and pre-mRNAs are regulated coordinately in vivo. J. Biol. Chem. 263:3845-3849.

15. Permutt, M. A., L. I. Koranyi, K. Keller, P. E. Lacy, D. W. Scharp, and M Mueckler. 1989. Cloning and functional expression of a human pancreatic islet glucose transporter cDNA. Proc. Natl. Acad. Sci. USA. 86:8688-8692.

16. Thorens, B., H. K. Sarkar, H. R. Kaback, and H. F. Lodish. 1988. Cloning and functional expression in bacteria of a novel glucose transporter present in liver, intestine, kidney, and B-pancreatic islet cells. Cell. 55:281-290.

17. Magnuson, M. A., and K. D. Shelton. 1989. An alternate promoter in the glucokinase gene is active in the pancreatic beta-cell. J. Biol. Chem. 264:1593615942.

18. Koranyi, L., M. A. Permutt, J. M. Chirgwin, and S. J. Giddings. 1989. Proinsulin I and II gene expression in inbred mouse strains. Mol. Endocrinol. 3:1895-1902.

19. Sambrook, J., E. F. Fritsch, and T. Maniatis. 1989. Molecular Cloning: A Laboratory Manual. 2nd ed. Cold Spring Harbor Laboratory, Cold Spring Harbor, NY.

20. Koranyi, L. I., R. E. Bourey, C. A. Slentz, J. O. Holloszy, and M. A. Permutt. 1991. Coordinate reduction of rat pancreatic islet glucokinase and proinsulin mRNA by exercise training. Diabetes. 40:401-404.

21. Permutt, M. A., and D. M. Kipnis. 1972. Insulin biosynthesis. II. Effect of glucose on ribonucleic acid synthesis in isolated rat islets. J. Biol. Chem. 12001207.

22. Brunstedt, J., and S. J. Chan. 1982. Direct effect of glucose on the preproinsulin mRNA level in isolated pancreatic islets. Biochem. Biophys. Res. Commun. 106:1383-1389.
23. Nielsen, D. A., M. Welsh, M. J. Casadaban, and D. F. Steiner. 1985. Control of insulin gene expression in pancreatic beta cells and in an insulin-producing cell line, RIN-5F cells. I. Effects of glucose and cyclic AMP on the transcription of insulin mRNA. J. Biol. Chem. 260:13585-13589.

24. Welsh, M., D. A. Nielsen, A. J. MacKrell, and D. F. Steiner. 1985. Control of insulin gene expression in pancreatic beta cells and in an insulin-producing cell line, RIN-5F cells. II. Regulation of insulin mRNA stability. J. Biol. Chem. 260:13590-13594.

25. Chen, L., I. Komiya, L. Inman, K. McCorkle, T. Alam, and R. H. Unger. 1989. Molecular and cellular responses of islets during perturbations of glucose homeostasis determined by in situ hybridization histochemistry. Proc. Natl. Acad. Sci. USA. 86:1367-1371.

26. German, M. S., L. G. Moss, and W. J. Rutter. 1990. Regulation of insulin gene expression by glucose and calcium in transfected primary islet cultures. $J$. Biol. Chem. 265:22063-22066.

27. Matchinsky, F. M. 1990. Glucokinase as glucose sensor and metabolic signal generator in pancreatic B-cells and hepatocytes. Diabetes. 39:647-652.

28. Iynedjian, P. B., P.-R. Pilot, T. Nouspikel, J. L. Milburn, C. Quaade, S Hughes, C. Ucla, and C. B. Newgard. 1989. Differential expression and regulation of the glucokinase gene in liver and islets of Langerhans. Proc. Natl. Acad. Sci. USA. 86:7838-7842.

29. Nishi, M., T. Sanke, S. Nagamatsu, G. I. Bell, and D. F. Steiner. 1990. Islet amyloid polypeptide: a new B cell secretory product related to islet amyloid deposits. J. Biol. Chem. 265:4173-4176.

30. Anderson, E. A., R. P. Hoffman, T. W. Balon, C. A. Sinkey, and A. L. Mark. 1991. Hyperinsulinemia produces both sympathetic neural activation and vasodilation in normal humans. J. Clin. Invest. 87:2246-2252.

31. O'Brien, R. M., and D. K. Granner. 1990. PEPCK gene as model of inhibitory effects of insulin on gene transcription. Diabetes Care. 13:327-339.

32. O'Brien, R. M., P. C. Lucas, C. D. Forest, M. A. Magnuson, and D. K. Granner. 1990. Identification of a sequence in the PEPCK gene that mediates a negative effect of insulin on transcription. Science (Wash. DC). 249:533-537.

33. Quinn, P. G., T. W. Wong, M. A. Magnuson, J. B. Shabb, and D. K. Granner. 1988. Identification of basal and cyclic AMP regulatory elements in the promoter of the phosphoenolpyruvate carboxykinase gene. Mol. Cell. Biol. 8:3467-3475.

34. Chu, D. T. W., C. M. Davis, N. B. Chrapkiewicz, and D. K. Granner. 1988. Reciprocal regulation of gene transcription by insulin. J. Biol. Chem. 263:13007-13011.

35. O'Brien, R. M., M. T. Bonovich, C. D. Forest, and D. K. Granner. 1991 Signal transduction convergence: phorbol esters and insulin inhibit PEPCK gene transcription through the same ten base pair sequence. Proc. Natl. Acad. Sci. USA. In press.

36. Leffert, J. D., C. B. Newgard, H. Okamoto, J. L. Milburn, and K. L. Luskey. 1989. Rat amylin: cloning and tissue-specific expression in pancreatic islets. Proc. Natl. Acad. Sci. USA. 86:3127-3130.

37. Ogawa, A., V. Harris, S. K. McCorkle, R. H. Unger, and K. L. Luskey. 1990. Amylin secretion from the rat pancreas and its selective loss after streptozotocin treatment. J. Clin. Invest. 85:973-976.

38. Bretherton-Watt, D., M. A. Ghatei, S. R. Bloom, H. Jamal, G. J. M. Gerrier, S. I. Girgis, and S. Legon. 1989. Altered islet amyloid polypeptide (amylin) gene expression in rat models of diabetes. Diabetologia. 32:881-883.

39. Koranyi, L., Y. Tanizawa, L. Penicaud, N. Atef, J. Girard, and M. A. Permutt. 1992. Developmental regulation of amylin and insulin gene expression in lean $(\mathrm{Fa} / \mathrm{Fa})$ and obese ( $\mathrm{fa} / \mathrm{fa})$ Zucker rats. Diabetes. In press. 